\title{
新しい先端形状を有したデュアルルーメン カテーテルの有用性
}

\author{
佐々木 敏作脇 川健山田明子少山禎之*1 \\ 和田茂*1 \\ 大阪掖済会病院内科 同人工透析室*1
}

key words : デュアルルーメンカテーテル, 先端形状, 血流不全, 合併症

〈要旨〉

血漿交換療法の適応疾患の拡大や, 免疫吸着療法あるいは脂質吸着療法の開発, 進歩により, デュアルルーメン カテーテル (DLC) を使用する機会はますます増加している. しかし, DLCの長期留置に際し, 最も問題となるの は脱血不良である.我々は以前よりこの脱血不良はDLC の先端形状と密接な関係があることを報告してきた. 今回, 我々が理想とするユニークな先端形状を有する DLC (Niagara ${ }^{\mathrm{TM}}$ )が開発されたので，弚の特性について他の 3 種類 の異なったタイプの DLC と比較検討した。凝血塊除去試験の結果, Niagara ${ }^{\mathrm{TM}}$ では吸引によりほぼ完全に脱血, 返 血孔に形成された凝血塊を除去することが可能であった. In vitro における血液再循環率はすべてのカテーテルでほ ぼ同様であった (4\%以下). また, Niagara ${ }^{\mathrm{TM}}$ はその径が太いことと挿入試験で抵抗力が大であったにもかかわらず, 実際の挿入に際しては従来のエンドホールタイプのカテーテルと異なりスタイレットを使用することで比較的容易 であった. Niagara ${ }^{\mathrm{TM}}$ を使用した 15 症例のうち 1 例のみが㠜血塊による脱血不良を認めた. 他の 14 例では定期的あ るいは連続的にヘパリン製剤や他の薬剤を注入することなく良好な血流が確保され, 透析は最長 37 日間連続して行 えた．若干の問題点はあるものの，現時点ではNiagara ${ }^{\mathrm{TM}}$ は最も優れた DLCであると考えられた．

\section{The efficacy of Dual-lumen catheters with a new tip shape}

Satoshi Sasaki, Takeshi Wakikawa, Akiko Yamada, Tadayuki Maruyama*1, Shigeru Wada*1 Department of Internal Medicine and Hemodialysis Section*1, Osaka Ekisaikai Hospital

The likelihood of placing Dual-lumen catheters (DLC) is increasing with the rise in the number of diseases for which plasma apheresis is efficacious and with the development of immunoadsorption and lipid adsorption. The most common problem resulting from long-term use of DLC is poor blood flow. We have previously reported that the tip shape of DLC and poor blood flow are closely related. Since the development of Niagara ${ }^{\mathrm{TM}}$, which has a unique tip shape similar to the ideal shape, we evaluated its properties in comparison with those of three other DLCs. In a clot-removing test, Niagara ${ }^{\mathrm{TM}}$ removed clots formed in arterial and venous lumens nearly perfectly by aspiration. There was no difference in the blood recirculation rate (in vitro : $<4 \%$ ) among these DLCs. Although Niagara ${ }^{\mathrm{TM}}$ has a large diameter and exhibited high resistance during an insertion test, it could be relatively easily inserted with a stylet, unlike the standard end-hole type catheter. Of 15 cases using Niagara ${ }^{\mathrm{TM}}$, only one exhibited poor blood flow due to clots. In the other 14 cases, there was sufficient blood flow without periodic or continuous injection of heparin or solutions into the catheter, and hemodialysis could be performed continuously for 37 days (longest). We consider Niagara ${ }^{\mathrm{TM}}$ the best DLC currently available despite a few shortcomings.

佐々木敏作 大阪掖済会病院内科厂550-0022 大阪市西区本田 2-1-10（06-6581-2881）

Satoshi Sasaki Fax 06-6584-1807 E-mail : sasakidr@mb.infoweb.ne.jp

〔受付: 平成 12 年 12 月 20 日, 受理: 平成 13 年 7 月 6 日〕 


\section{緒言}

従来，急性腎不全あるいは慢性腎不全の急性増悪時 の緊急透析や，維持血液透析患者の内シャント閉塞の 場合，その一時的ブラッドアクセスとしてデュアル ルーメンカテーテル（DLC）が用いられてきた，急性 腎不全では回復期までの期間, 慢性腎不全の場合は内 シャント造設までの期間, カテーテルを必要とするが, それ以上長期間使用する必要性はなかった。しかし， 血漿交換療法や免疫吸着療法, 脂質吸着療法などの開 発, 進歩に伴い, DLC をより長期間留置する機会が増 加している。また CHDF 療法が確立して DLCを 24 時間安定して連続使用できる機能が求められている。 しかし, DLCは一時的ブラッドアクセスとして比較的 簡便に留置できる反面, 長期間あるいは長時間連続使 用に際してはいろいろな問題点が指摘されている。す なわち，留置静脈の閉塞 ${ }^{1,2)}$, カテーテルを通じての感 染3), 脱血不良などである.

最も遭遇し, 問題となるのは脱血孔からの血流不足 による血液净化療法の中断であり，そのためDLCの 交換を余儀なくされることもしばしばである. 脱血不 良の頻度については報告により異なるが，抒抒むね留 置症例の $15 \%$ 以上が脱血不良によりカテーテルの交 換を余儀なくされている

この脱血不良の原因のほとんどはDLC内に形成さ れた凝血塊によるものであり，その形成を防止する目 的で脱血孔のサイズや配置を変更したもの ${ }^{5,6)}$ ，あるい はヘパリンやウロキナーゼといった抗血栓作用を示す 薬㨈をDLC 内面にコーティングしたものなどが種々 開発されているが7,8)必ずしも満足した結果は得られ ていない.またDLCの管理としては，その閉塞を防ぐ 目的でカテーテル内へ定期的にヘパリン製剤を充填す る方法が最も一般的である。その他携帯型ディスポー ザブル持続注入ポンプを用いて薬液を微量注入する方 法9)や，あるいはオプチュレーターを挿入する方法な ども凝血塊の形成防止目的で推奖されているが，上記 いずれの方法も操作が煩雑で, 効果が不十分であるば
かりでなく，その処㯰のためカテーテル感染の危険性 も高いと考えられる.さらに，ヘパリン製剤の頻回注 入では凝固系への影響も無視できない.またそういっ た操作の必要性は患者の活動性にも弊害となってい る。

以上の観点から, 我々は各種 DLCの比較検討を行 い,「凝血塊形成の防止」より「形成凝血塊の除去」が 血流確保にとって最も重要であることを報告してき た ${ }^{10)}$.さらに, 凝血塊除去能は DLCの先端形状により 大きく左右され，単孔でエンドホールタイプの DLC が最も優れていた，今回我々が理想とする先端形状に 類似したDLC (Niagara ${ }^{\mathrm{TM}}$; BARD) が開発されたの で，その特性について検討した。

\section{I. 方 法}

比較検討したDLC は以下の 4 種類である，脱血孔 が複数個の小孔で，カテーテルの側面 $1 / 3$ 周に開口し ているもの (DLC-4400；Gambro，以下 SH と略す). 上記と同様の脱血孔がカテーテル側面の全周に開口し ているもの (CXC-4400；Gambro，以下 CA と略す). 脱血孔，返血孔とも比較的大きな単孔で，エンドホー ル形状となっているもの(BAC-D 1020 ； FC, 以下 $\mathrm{EH}$ と略す)，今回新たに検討を加えた Niagara ${ }^{\mathrm{TM}}(\mathrm{NK} 20$ J) は全体としてエンドホール形状をとっているが，脱 血孔が約 30 度傾斜していて, その側面に極小の補助脱 血孔が 2 個開孔している。またシースを用いて挿入す る $\mathrm{EH}$ と異なりスタイレットを用いることで挿入性 の向上が図られている。各種 DLCの仕様は表 1 に示 した。これらのDLCを用いて in vitroでの凝血塊除 去性, 血液再循環率および挿入性試験を以下の条件で 比較検討した。さらに Niagara ${ }^{\mathrm{TM}}$ の臨床応用例につい ても報告する。

凝血塊除去性試験：試験管内に採取した健常人の血 液中に各 DLCを 30 分間留置し強制的に DLC 内に凝 血塊を形成させた後，脱血側および返血側にそれぞれ $10 \mathrm{ml}$ のシリンジを接続し緩徐に陰圧をかけ凝血塊の 吸引を行った。

表 1 各カテーテルの仕様

\begin{tabular}{|c|c|c|c|c|}
\hline カテーテル & SH & $\mathrm{CA}$ & $\mathrm{EH}$ & Niagara $^{\mathrm{TM}}$ \\
\hline 外形 (F) & 10.8 & 11 & 10 & $19 \times 11$ \\
\hline 先端形状 & サイドホール & コアクシャル & エンドホール & エンドホール \\
\hline 脱血孔 & $1.5 \mathrm{~mm} \times 6$ & $1.5 \mathrm{~mm} \times 8$ & $2.6 \mathrm{~mm}$ 半円 & $2.2 \mathrm{~mm}$ 棈円 \\
\hline 返血孔 & $1.2 \mathrm{~mm} \times 7$ & $1.2 \mathrm{~mm} \times 5$ & $2.6 \mathrm{~mm}$ 半円 & $2.2 \mathrm{~mm}$ 真円 \\
\hline 素 材 & 親水性ポリウレタン & 親水性ポリウレタン & 親水性ポリウレタン & 親水性ポリウレタン \\
\hline
\end{tabular}


血液再循環率試験：in vitroでは生理食塩水にてへ マトクリット值を $25 \%$ に調整した人赤血球濃厚液 (MAP) $520 \mathrm{~m} l$ を擬似血管内で循環させ，その内部に 留置した各DLCにおける血液再循環率をCLIT-

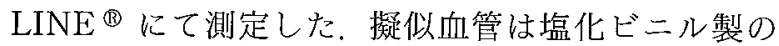
チューブを用い，中心静脈に類似するよう内径 12 $\mathrm{mm}$, 平均血液流速 $11 \mathrm{~cm} / \mathrm{s}$, 管内圧 $0 \sim 10 \mathrm{mmHg}$ に 設定した。またin vivoでは安定した体外循環時に CLIT-LINE @ 用い生理食塩水希䣋法にて血液再循 環率を測定した。

挿入試験：カテーテルの全体形状と血管内留置時の 挿入性について検討する目的で，以下の試験を行った． 市販のこんにゃく（「山の味」脇田食品工業（株））を 用い, 各カテーテルを $100 \mathrm{~mm} / \mathrm{min}$ の速度で垂直に挿 入し，受ける抵抗力 (gf) をインストロン型オートグラ フ (島津 $\mathrm{AG}-50 \mathrm{kNE}{ }^{\circledR}$ ) にて測定し比較検討した。

\section{II。結果}

図 1 は $\mathrm{SH}$ と CA の凝血塊形成時とその吸引結果 を示している。凝血塊形成時（図 1 左）は脱血および 返血孔がすべて閉塞しておう，吸引後（図 1右）はそ れぞれ一部の小孔のみ開存し残りの小孔に付着した凝 血塊は吸引除去できなかった。一方, EH, Niagara ${ }^{\mathrm{TM}}$ では形成された凝血塊は脱血，返血孔ともにほ㴗完全 に吸引除去可能であった（図 2）。

各 DLC を同一条件で比較するため，擬似血管を用 いin vitroでそれぞれの再循環率を測定した，表 $2 \mathrm{~A}$ に示すとおり血液流量 $100,200,300 \mathrm{~m} l / \mathrm{min}$ では各 DLC の再循環率に差はなく，いずれも4\%以下であり 臨床上も特に問題岒ないと考光られた。In vivoでは

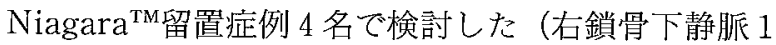
例, 右内頸静脈 3 例)．表 2 B に示すように鎖骨下静脈 に留置した例で，QB $200 \mathrm{~m} l / \mathrm{min}$ で再循環率 8.56\% とやや高值であったが，それ以外は約 $3 \%$ であった。

挿入性試験の結果は図 3 に示した，EH は本来シー スを用い体内に挿入するため今回の挿入性試験法行え なかった，そこで，残りの 3 種の DLCで比較検討し た. $\mathrm{SH}, \mathrm{CA}$ とも先端の挿入部分 (A 点) で高い抵抗 を示すが，その後は外形の太さに依存すると思われる なめらかな圧力の上昇を認めた。 Niagara ${ }^{\mathrm{TM}}$ はス夕イ レットと返血孔との段差の部分（B 点）でわずかに抵 抗が高く, また脱血孔の傾斜部 ( $\mathrm{C}$ 点) では高い抵抗力 を示した。

次に，実際の臨床応用例を示す．15例について使用 したが，その概要は表 3 に示したとおりである，症例
表 $2 \mathrm{~A}$ in vitroにおける各カテーテルの血液 再循環率 (\%)

\begin{tabular}{|c|c|c|c|c|c|c|}
\hline \multirow{2}{*}{ カテーテル } & \multicolumn{6}{|c|}{$\mathrm{QB}(\mathrm{m} l / \mathrm{min})$} \\
\hline & \multicolumn{2}{|c|}{100} & \multicolumn{2}{|c|}{200} & \multicolumn{2}{|c|}{300} \\
\hline $\mathrm{SH}$ & $<1$ & $<1$ & $<1$ & 2.24 & $<1$ & 1.73 \\
\hline $\mathrm{CA}$ & $<1$ & $<1$ & 1.68 & $<1$ & $<1$ & $<1$ \\
\hline $\mathrm{EH}$ & 2.83 & $<1$ & $<1$ & $<1$ & $<1$ & 1.02 \\
\hline Niagara $^{\mathrm{TM}}$ & $<1$ & $<1$ & 3.33 & $<1$ & 2.39 & 2.61 \\
\hline
\end{tabular}

表 2B in vivoにおける Niagara ${ }^{\mathrm{TM}}$ の血液 再循環率 (\%)

\begin{tabular}{c|c|c|c|c}
\hline \multirow{2}{*}{ 症 例 } & \multirow{2}{*}{ 留置部位 } & \multicolumn{3}{|c}{$\mathrm{QB}(\mathrm{m} l / \mathrm{min})$} \\
\cline { 3 - 5 } & & 100 & 150 & 200 \\
\hline 70 歳, 女 & 右鎖骨下静脈 & 2.08 & $<1$ & 8.56 \\
52 歲, 女 & 右内頸静脈 & 1.94 & $<1$ & 3.03 \\
40 歳, 女 & 右内頸静脈 & 1.08 & $<1$ & 2.52 \\
58 歳, 女 & 右内頸静脈 & $<1$ & $<1$ & 3.01 \\
\hline
\end{tabular}

10，13 㹥当初 CA を使用したが, 返血圧の上昇や血流 不良のため Niagara ${ }^{\mathrm{TM}}$ に変更した。表に示すように留 置期間は 1 日から最長 37 日であった. Niagara ${ }^{\mathrm{TM}}$ は他 のカテーテルに比べてその径が太く，脱血孔が段差と なっているため挿入時にかなりの抵抗感が予想された が，実際にはスタイレットの使用と相まってスムーズ に挿入でき，テーパリング形状をとる SH や CA と同 様の感触であった，体外循環開始時には脱血，返血側 よりそれぞれ数 $\mathrm{m} l$ の生理食塩水を満たしたシリンジ にてカテーテル内に形成された凝血塊（浪とんどの症 例で毎回凝血塊が認められた）を吸引除去し，回路に 接続し，何ら問題なく有効な血流が得られた。また体 外循環終了時にはカテーテル内に生理食塩水を充填す るのみで，とくにへパリンなどは充填せず，また体外 循環を行わない日にも一切の薬液の注入も行わなかっ た。

カテーテル留置に伴う合併症は表 4 に示したと扔り 非常に少ないものであった。症例 3 においては 2 回目 の体外循環終了後脱血不良を起こし，拢去を余儀なく されたが，脱血不良はこの 1 回のみであり，これは表

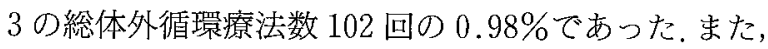
症例 11 はカテーテル感染による熱発を認めたため抜 去した，挿入部位の比較では鎖骨下静脈が 6 名，内頸 静脈が 7 名, 大腿静脈が 2 名であったが，いずれの場 所でも有効な血流が確保できた。 ただし，挿入時の印 象では内頸静脈，大腿静脈に比して，鎖骨下静脈では やや抵抗が大きい感触が得られたが，特に挿入に困難 な症例はなかった。最後に DLC 留置に伴う晚期合併 症である鎖骨下静脈狭窄症について検討した，鎖骨下 


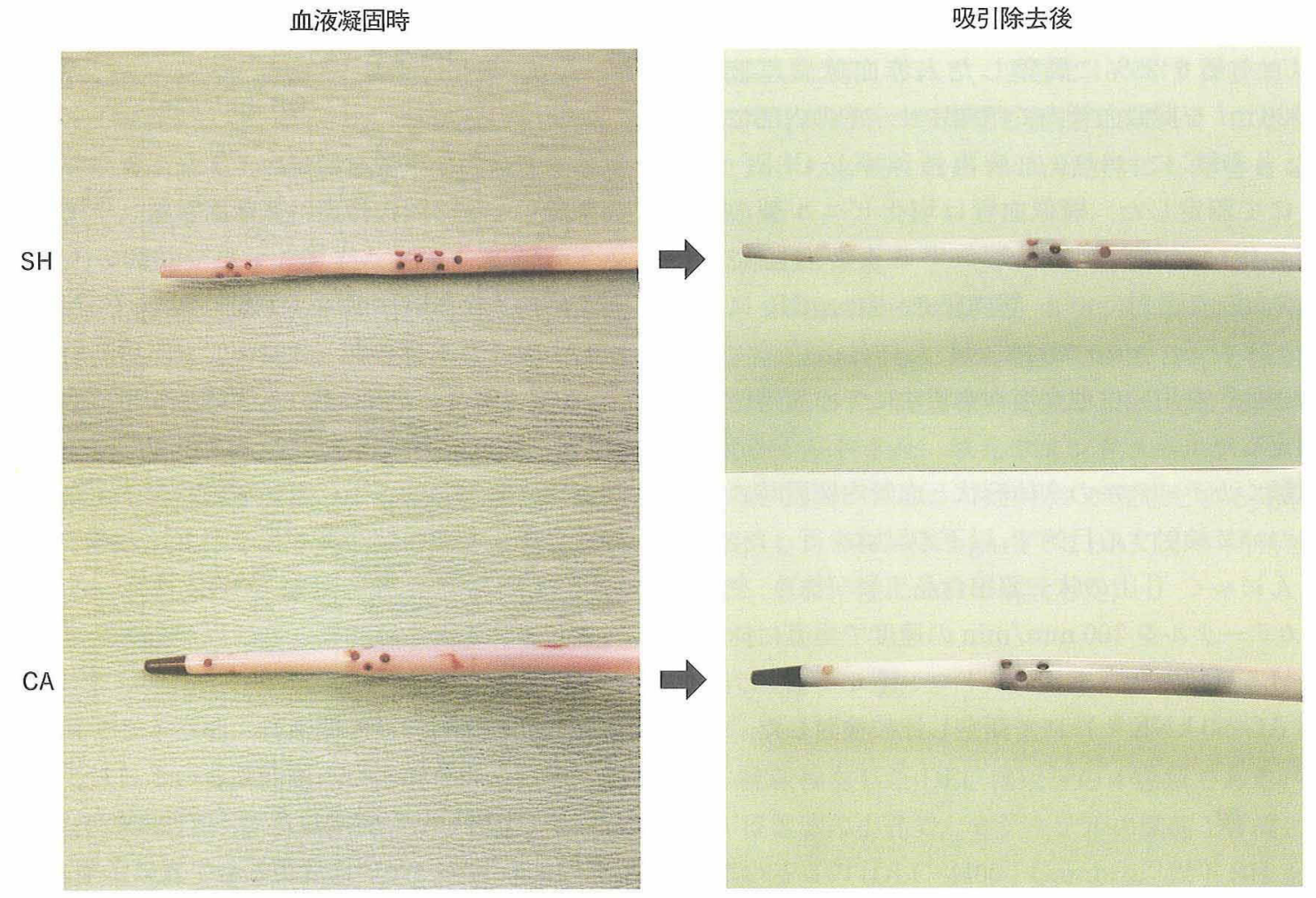

図 1 SH，CA の凝血塊除去試験

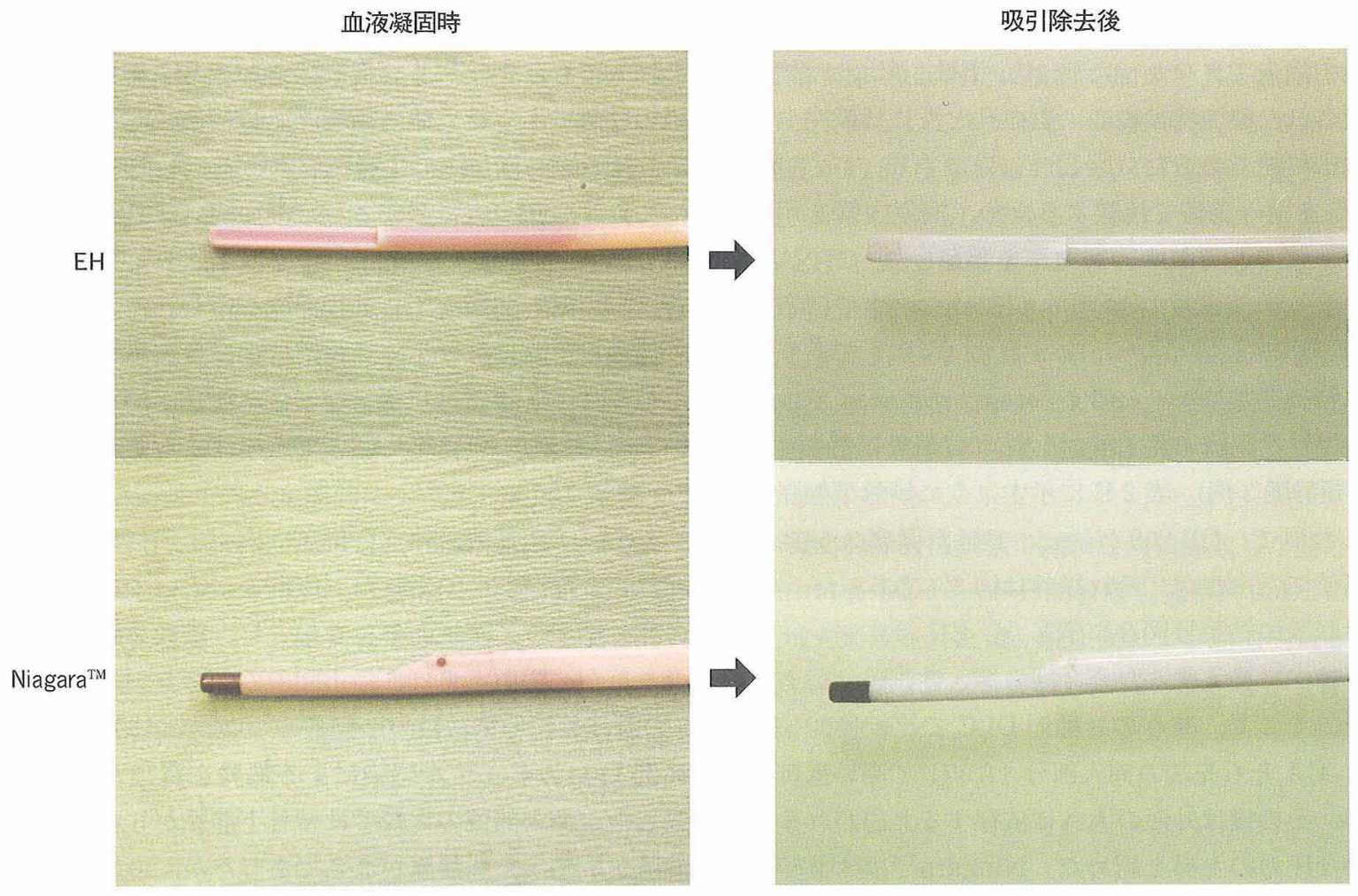

図 $2 \mathrm{EH}$, Niagara ${ }^{\mathrm{TM}}$ の凝血塊除去試験 


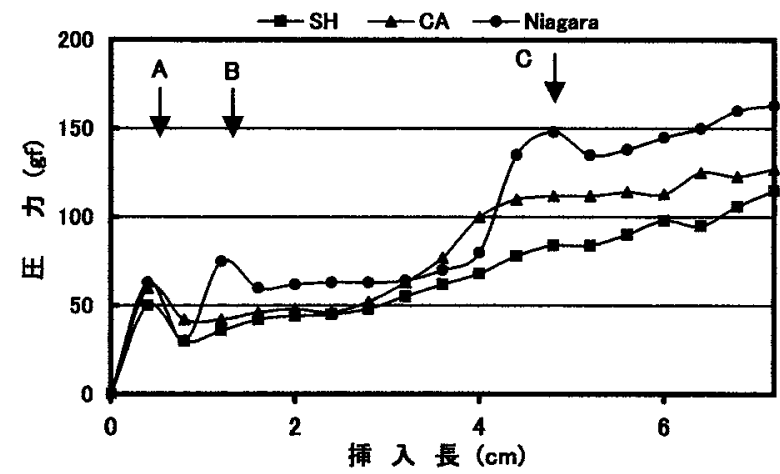

図 3 各カテーテルの挿入時圧の比較
表 4 Niagara ${ }^{\mathrm{TM}}$ 留置症例の合併症

\begin{tabular}{c|c}
\hline 内 容 & 頻度 $(/ 15$ 症例 $)$ \\
\hline 脱血不良 & 1 \\
発 熱 & 1 \\
出血, 血腫 & 0 \\
カテーテルの破損 & 0 \\
自然抜去 & 0 \\
\hline
\end{tabular}

表 3 Niagara ${ }^{\mathrm{TM}}$ 留置症例

\begin{tabular}{|c|c|c|c|c|c|c|c|}
\hline 症例 & 年齢, 性別 & 原疾患 & 法 & 回数 & 留置部位 & 留置期間(日) & 経 過 \\
\hline 1 & 70 歳, 女 & 慢性腎不全 & HD & 16 & 右鎖骨下 & 34 & 死 亡 \\
\hline 2 & 52 歳, 女 & 慢性腎不全 & HD & 11 & 右内頸 & 22 & CAPD \\
\hline 3 & 74 歳, 女 & 心不全 & ECUM & 3 & 左鎖骨下 & 9 & 死 亡 \\
\hline 4 & 40 歳, 女 & 慢性腎不全 & $\mathrm{HD}$ & 11 & 右内頸 & 28 & 内シャント \\
\hline 5 & 57 歳, 女 & Fisher's 症候群 & IAPP & 2 & 右大腿 & 5 & 死 亡 \\
\hline 6 & 62 歳, 男 & 慢性腎不全 & HD & 16 & 右鎖骨下 & 37 & 離 脱 \\
\hline 7 & 58 歳, 女 & 急性腎不全 & HD & 15 & 右内頸 & 33 & 内シャント \\
\hline 8 & 50 歳, 女 & 肝不全 & $\mathrm{HDF}$ & 3 & 右内頸 & 24 & 死 亡 \\
\hline 9 & 63 歳, 男 & 敗血症性ショック & $\mathrm{HDF}$ & 1 & 右大䬶 & 2 & 死 亡 \\
\hline 10 & 50 歳, 女 & 慢性腎不全 & ECUM/HD & 3 & 右鎖骨下 & 7 & 内シャント \\
\hline 11 & 58 歳, 男 & 慢性腎不全 & HD & 4 & 右内頸 & 9 & 離＼cjkstart脱 \\
\hline 12 & 39 歳, 男 & 慢性腎不全 & HD & 8 & 右内頸 & 20 & 内シャント \\
\hline 13 & 86 歳, 女 & 心不全 & ECUM & 1 & 右鎖骨下 & 1 & 離＼cjkstart脱 \\
\hline 14 & 27 歳, 男 & 劇症肝炎 & $\mathrm{CHDF} / \mathrm{PE}$ & 6 & 右内頸 & 7 & 肝移植 \\
\hline 15 & 63 歳, 女 & SIRS & HDF & 2 & 右鎖骨下 & 5 & 死 亡 \\
\hline 合計 & 15 名 & & & 102 & & 平均 16.2 日 & \\
\hline
\end{tabular}

静脈に留置した症例 6 例のうち，離脱や死亡例を除く と，その後の経過を追えたのは 1 例（症例 10）のみで あった。本症例は左前腕に内シャントを作製し， Niagara ${ }^{\mathrm{TM}}$ 抜去後約 14 か月維持血液透析を受けてい るが, 臨床的には鎖骨下静脈狭窄症状は認めなかった。

\section{III. 考 察}

一般に血液透析患者において，内シャント作成不能 例や内シャント再建不能例には外シャント，大腿静脈 直接穿刺法, 動脈直接穿刺法, 動脈表在化法などが用 いられているが，その簡便性や，頻回使用に耐えられ る点で, DLCが最も優れた一時的ブラッドアクセスで あるのはいうまでもない。 さらに，わが国では維持血 液透析患者の高齢化や長期予後の改善に伴い, シャン トトラブルが増加しており，そのためより長期に DLC を使用することが求められている。また，各種疾患に 体外循環を必要とする治療法が開発され，より DLC
の使用機会は増すばかりである。しかし，DLCを長期 留置するにあたり最も問題となるのは脱血不良であ り，その原因のほとんどがカテーテル内部に形成され た凝血塊である。そのため現在までのカテーテルにつ いての報告の多くはその凝血塊の形成防止という観点 から論じられてきた ${ }^{11)}$.しかし，我々はDLCの先端形 状がその脱血不良と密接な関係があると考えてきた。

すなわち形成された凝血塊を簡単に除去できることが 重要であり，それにはカテーテルの先端が基本的にエ ンドホール構造をもつことと考えている，これは，長 期留置の体内埋め込み型カテーテルの先端がエンド

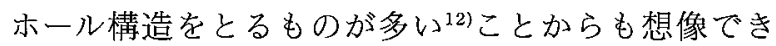
る.

今回 Niagara ${ }^{\mathrm{TM}}$ を他の 3 種の DLC と比較検討した 結果，予想どおり $\mathrm{EH}$ タイプと同様に凝血塊の除去に 優れていた。しかも挿入については, 純粋なエンドホー ル形状を持つ $\mathrm{EH}$ タイプと異なりシースを必要とせ ず，また挿入試験のデータに反し実際の挿入は比較的 
容易であった。 また血液再循環率は in vitro では他の 3 種の DLC と大差なく低值であった。一方 in vivoで は症例 1 において QB $200 \mathrm{~m} l / \mathrm{min}$ 時で $8.56 \%$ と高值 であったが，この数字は過去の報告 ${ }^{13)}$ と比べても臨床 使用上特に問題となるレベルではなかった，実際の Niagara $^{\mathrm{TM}}$ の臨床使用例では 15 例中 1 例が㠜血塊に よる脱血不良を起こしたのみであった。これは総体外 循環療法数（102 回）の $0.98 \%$ でり非常に優れたも のと考元られた，従来 DLC と回路を接続する際, 脱血 不良が起こった場合のみへパリン加生理食塩水を満た したシリンジで吸引する方法が推奨されているが ${ }^{44)}$, Niagara $^{\mathrm{TM}}$ の場合には DLC の先端に凝血塊が形成さ れていることがほとんどなので, 回路への接続前に必 ず形成された凝血塊を吸引することが重要である。ま たこの時決してシリンジでフラッシュして凝血塊を体 内に押し込む操作㹥避けなければならない。ささらに体 外循環を行わない間，定期的あるいは連続的にへパリ ン製剂等をDLC 内に注入する必要はない。このこと は当然 DLCへの処置回数が隇少し, 感染の機会や凝 固系への影響が減少するばかりでなく，患者の活動制 限も緩和されると考元られる。実際我々の施設では, 全身状態の良い患者についてはDLC を留置したま ま, シャワー浴や外泊を可能とし, 永続的ブラッドア クセスの十分な発達までの間の患者の活動性を保持し ている. 今回の臨床応用例では Niagara ${ }^{\mathrm{TM}}$ の最長留置 期間は 37 日であったが, これは患者が透析離脱できた ためで，さらに長期留置使用可能との印象を持ってい る.もし Niagara ${ }^{\mathrm{TM}}$ が数か月留置使用可能となれば, 埋め込み型 DLC に匹敵する可能性学秘めており，ま たそのカテーテル交換の簡便性を考慮すれば，むしろ 埋め込み型 DLC より有用性が高いとも考光られる。

しかし, Niagara ${ }^{\mathrm{TM}}$ は他の 3 種の DLC に比較しその 径が大きく，また断面形状も全体として棈円形である ため, 長期留置に伴う静脈閉塞（特㳊鎖骨下静脈狭窄 症）の危険性は増加する可能性がある。DLC の留置期 間あるいはその形状と晚期合併症である鎖骨下静脈狭 窄症との関連については一致した見解が得られていな いが15,16)，本研究に执いても症例数が少なく検討でき なかった。しかし，挿入性試験の結果からもより径の 細い夕イプが望ましいと思われた。また，我々は極小 の補助脱血孔は必要ないと考えている。この小孔は QB $400 \mathrm{~m} l / \mathrm{min}$ まで確保する目的で作られているが， 本邦においてはそこまでQBを確保することはなく (これは日米における HD の違いであるが)，むしろこ の補助孔のため脱血孔の先端にできた凝血塊の吸引除 去が不十分になる可能性があると思われた。これら若
干の問題点はあるものの, Niagara ${ }^{\mathrm{TM}}$ は現時点では最 も優れたDLCであり，今後さらに臨床応用例が増加 するにつれ，ますますその利便性が確認されることと 思われる。

謝辞：カラーテルの挿入性試験に協力いただいた大阪市 立工業研究所の喜多氏纪感謝します。

\section{文献}

1) Vanherweghem JL, Cabolet $P$, Dhaene M, Goldman M, Stolear JC, Sabot JP, Waterlot Y, Marchal M : Complication related to subclavian catheters for hemodialysis. Am J Nephrol 6:339-345, 1986

2）提嶋淳一郎, 太田和夫, 鈴木利昭, 長沼信治, 中里 聰, 久保和雄：ブラッドアクセス合併症としての鎖骨下静 脈狭窄症抢よび血栓症。腎と透析 11：133-137，1991

3) Marr KA, Sexton DJ, Conlon PJ, Corey GR, Schwab SJ, Kirkland KB : Catheter-related bacteremia and outcome of attempted catheter salvage in patients undergoing hemodialysis. Ann Intern Med 127 : 275280,1997

4）中嶋史郎，木村文宏，鈴木知史，瀬口健至，大道雄一 郎, 浅野友彦, 辻明, 早川正道, 中村 宏: 大腿 静脈カテーテルを用いた血液透析の問題点．透析会誌 $29: 1485-1489,1996$

5）後藤洋右, 高嶺芳孝, 安部 博, 久木田和丘, 米川元 樹, 川村明夫：血液透析におりる全周性多孔型ダブル ルーメンカテーテルの使用経験。薬理と臨床 5：10191021, 1995

6）米川元樹，久木田和丘，目黒順一，川村明夫，高橋昌 宏, 柳田尚之, 倉内宣明, 池田 篤: 血液浄化におけ る Double lumen カテーテルの形状の検討。薬理と臨 床 $4: 1405-1408,1994$

7）池上修生，木村文宏，池田義弘，床鍋繁喜，瀬口健至， 鈴木知史, 住友 誠, 过明, 小田島邦男, 浅野友 彦, 早川正道, 中嶋史郎：大腿静脈留置ウロキナーゼ. コーティング・カテーテルの合併症．透析会誌 32 ： $1117-1120,1999$

8）久木田和丘，安原満夫，米川元樹，小山内誠，内藤昌 明, 鹿取正道, 田中三津子, 高橋昌宏, 玉置 透, 目 黒順一，川村明夫：新しく開発されたへパリンコー ティングカテーテルの使用経験. 医工学治療 $10 ： 164-$ 166, 1998

9）上田陽彦，平井 景，金原裕則，鈴木利明，日下 守， 上田清美，中内すすみ，岡本幸子，山田喜代志，松本 澄枝, 加納 和, 加納茂照: 血管留置用ダブルルーメ ンカテーテルの管理におけるシュアーフューザーA の使用経験。腎と透析 6：924-926，1995

10）佐々木敏作, 丸山禎之, 安藤里子, 和田 茂：ダブル ルーメンカテーテルの先端形状とその特性. 薬理と臨 床 6:1729-1732, 1996

11）北本康則, 菅井久子, 門間弘道, 石崎 允, 高橋 寿, 
関野 宏, 藪下安紀, 岩淵国人：ウロキナーゼ固定化 フェモラールベインカテーテル (UKFC) の抗血栓性 に関する研究. 人工臟器 $16: 767,1987$

12) McDowell DE, Moss AH, Vasilakis C, Pillai L: Percutaneously placed dual-lumen silicon catheters for long-term hemodialysis. Am Surg 59 : 569-573, 1993

13) Leblanc M, Fedak S, Mokris G, Paganini EP: Blood recirculation in temporary central catheters for acute hemodialysis. Clin Nephrol 45:315-319, 1996

14）平澤博之編：CHDF の理論と実際一原理·施行法
編一１7-23，総合医学社，東京， 1998

15) Spinowitz BS, Galler M, Golden RA, Rascoff JH, Schechter L, Held B, Charytan C : Subclavian vein stenosis as a complication of subclavian catheterization for hemodialysis. Arch Intern Med 147:305307, 1987

16) Wanscher M, Frifelt JJ, Smith-Sivertsen C, Andersen AP, Rasmussen AD, Sanchez Garcia R, Kohler $\mathrm{F}$ : Thrombosis caused by polyurethane doublelumen subclavian superior vena cava catheter and hemodialysis. Crit Care Med 16 : 624-628, 1988 